\title{
SOUTH AFRICAN CORRESPONDING AUTHORS ON PERCEIVED BENEFICIARIES AND THE NATURE OF UNIVERSITY RESEARCH
}

\author{
N. Boshoff \\ Centre for Research on Evaluation, Science and Technology (CREST) and DST-NRF Centre of \\ Excellence in Scientometrics and Science, Technology and Innovation Policy (SciSTIP) \\ Stellenbosch University \\ Stellenbosch, South Africa \\ e-mail: scb@sun.ac.za
}

\section{ABSTRACT}

About 2000 corresponding authors of articles in the Web of Science (who had a South African university address) selected from a list of 22 categories the perceived beneficiaries of their research. A beneficiary was defined as an entity that is either directly affected by the research results or that has a direct interest in the outcome of the research. The objective was to classify the corresponding authors into meaningful clusters based on similarities in their responses about the perceived beneficiaries, and to construct a profile for each cluster in terms of eight measures of basic research. Eleven beneficiary clusters were identified and appropriately labelled. Three of the clusters with a combined share of 42 per cent had an almost exclusive focus on the research and academic community. Respectively 33 per cent and 59 per cent of 'pure basic research' and 'oriented basic research' projects appeared in clusters that contained beneficiaries from outside the public research and academic communities.

Keywords: basic research, corresponding author, beneficiary, university

\section{INTRODUCTION}

Contemporary universities cannot afford to operate as academic enclaves. Being an integral part of society and occupying a central position in different conceptions of contemporary science systems (e.g. Mode 2 knowledge production, innovation systems and triple helix, Hessels and Van Lente 2008), universities are expected to demonstrate societal relevance. The quest for societal relevance means that universities need to develop an informed understanding of and sensitivity to their multiple audiences in all spheres of society. For universities to survive in a highly competitive global environment, they need to know who their stakeholders are and how best to interact with a broad spectrum of stakeholders that often portray fundamentally different needs and expectations. Alves, Mainardes and Raposo $(2010,160)$ use a definition of stakeholders that was developed by Freeman (1984) for strategic organisational management: 'any individual or group of individuals either impacted upon by the company or able to impact 
on the achievement of its objectives'. Stakeholders may exist in relation to any of the core functions of a university, i.e. research, teaching and community service. In this article, the focus is on the stakeholders of university research.

A stakeholder of research, to be precise, is someone with an interest in either the input or outcome of research, or someone who is affected or influenced by the research (Milligan, Hills, Smith and Le Tissier 2004). For the purpose of the current study, a research stakeholder was defined as an entity with either direct interest in the outcome of a specific research project or an entity that is directly affected by the results of that research. Thus, although the current study closely followed the description by Milligan et al., there was a difference in that research stakeholders were defined here solely in terms of the perceived outcome and benefit of research. Input to research (e.g. funding) did not feature in the definition of stakeholders used by the current study, neither did the study consider other indicators of stakeholders, such as the contributors to the research processes (e.g. collaborators) or those acting as intermediaries in disseminating the research findings. In essence, then, the current study narrowly defined a research stakeholder as a research beneficiary. This was done with three objectives in mind:

- $\quad$ to identify the perceived beneficiaries of university research as indicated by the South African corresponding authors of articles in the Web of Science (WoS), where the term 'beneficiaries' refers to predefined categories such as ‘own university', 'micro, small and medium businesses' and 'charities and private foundations';

- to cluster the corresponding authors into meaningful groups on the basis of similarities in their responses about the beneficiaries of their research; and

- $\quad$ to profile the identified clusters in terms of measures of basic research that correspond to the 'epistemological', 'intentional' and 'distance to application' criteria of Calvert (2004), together with measures of more applied or utility research.

The third objective focussed on the 'research' part of the research beneficiary or, put differently, the nature of the research involved. This required some reflection on the notion of basic research, which is discussed next.

\section{THE NOTION OF BASIC RESEARCH}

The distinction between basic and applied research, as articulated by the Organisation for Economic Co-operation and Development (OECD) in its guideline for the measurement of national research and development (R\&D), is well established. Accordingly, basic research is 
'experimental or theoretical work undertaken primarily to acquire new knowledge of the underlying foundations of phenomena and observable facts' (OECD 2002, 77), and can be either of the following:

Pure basic research is carried out for the advancement of knowledge, without seeking long-term economic or social benefits or making any effort to apply the results to practical problems or to transfer the results to sectors responsible for their application (OECD 2002, 78).

Oriented basic research is carried out with the expectation that it will produce a broad base of knowledge likely to form the basis of the solution to recognised or expected, current or future problems or possibilities. (OECD 2002, 78).

At the other end of the scale is applied research, which, according to the OECD, also means original investigation to acquire new knowledge. The difference is that the research is 'directed primarily towards a specific practical aim or objective' (OECD 2002, 78). These OECD definitions classify pure basic, oriented basic and applied research into separate categories along a single dimension, where the practical application aspect of each is interpreted respectively as non-existing, vague and specific.

There is also dissent to the widespread belief that basic (i.e. pure and oriented) and applied research activities represent separate categories along a one-dimensional spectrum. One dissentient was Stokes (1997) who coined the term 'Pasteur's quadrant' to refer to projects that extend the frontiers of knowledge and which are driven simultaneously by considerations of use. Basic and applied research activities are therefore not necessarily mutually exclusive, as implied by the OECD definitions (OECD 2002). Evidence to this end can be found in a number of international studies (e.g. Bentley, Gulbrandsen and Kyvik 2015), as well as a South African study by Mouton (2001).

Basic research often takes on different meanings for different actors in the science system. Calvert (2004) reported six criteria that both scientists and policy makers use to distinguish basic research from other research types.

The 'epistemological criterion' encapsulates a number of insights, all pertaining to the nature of knowledge or the types of knowledge produced. Following this criterion, in Calvert's (2004) study, basic research means research that is unpredictable and novel (expanding the frontiers of existing knowledge), general (applying to a broad range of phenomena and problems), theoretically driven, and reductional (understanding a phenomenon in terms of its basic entities, e.g. at molecular level). The 'intentional criterion', on the other hand, defines basic research in terms of the intention or aim of the researcher, specifically where the intention is not to produce something that will result in an application but rather to act upon and follow one's research curiosity. The remaining four criteria reported by Calvert (2004) are the - 
- 'distance from application criterion' (the further from application, the more basic the research);

- 'institutional criterion' (the name or classification of the institution where the research is conducted gives an indication of the degree or type of basic research);

- 'disclosure criterion' (the findings of basic research are communicated to other scientists and published in the scientific literature); and

- $\quad$ 'scientific field criterion’ (certain fields, such as astronomy and particle and nuclear physics, are deemed more basic than others).

As stated, only the 'epistemological', 'intentional' and 'distance to application' criteria for basic research featured in the current study. Before discussing the study methodology, a comment is warranted concerning the link between the nature of research and the perceived research beneficiaries. Given that basic and applied research activities could co-exist in the same project, the non-academic audiences that stand to benefit from the applied research cannot be isolated from the basic research aspects of that project. The expectation therefore was that non-academic project beneficiaries could also be claimed for basic research activities, given that 'the goals of knowledge and use can coexist in basic research' (Boggio, Ballabeni and Hemenway 2016, 182).

\section{METHODOLOGY}

The online version of the WoS was used to download the bibliographic details of a set of articles meeting the following criteria: published between 2011 and 2013, and listing any of the (then) 23 South African public universities in the address field of the corresponding author (called 'reprint author' in the WoS). This produced a list of 15620 articles. Of these, 14703 included an email address for the South African-based corresponding author. The remaining 917 articles either did not specify an email (848) or listed an email which was clearly not that of the corresponding author (69).

Since any corresponding author could be responsible for more than one article in the dataset, a smaller set of 'unique' corresponding authors had to be identified. This was done by randomly selecting one article for each corresponding author. In doing so, a list of 6624 unique author names and email addresses was created. These 6624 corresponding authors were regarded as a proxy for the principal investigators of the projects on which the articles reflected. Each corresponding author received an email that requested his or her participation in a web 
survey, and which provided a hyperlink to access the relevant questions. All email requests were distributed via a mail merge in MS Word. A mail merge was needed as the individual emails had to include the bibliographic details of the selected article (title, journal and publication year) that comprised the focus of the survey, as well as a unique article number for the respondent to type into the online questionnaire. Having a unique article number for each submitted questionnaire enabled the linking of the responses to the WoS subject categories of the journal in which the article appeared.

Two multiple-response questions had to be answered with the selected article in mind. The first question involved a list of 22 beneficiary categories. These categories met the requirement of face validity and were purposively designed to generate a comprehensive list of possible entities (in all sectors of society) which stood to benefit from the research. The respondents had to reflect on the research that led to their article and then indicate which of the beneficiary categories they believed either had a direct interest in the outcome of their study or were directly affected by its results. Multiple selections were possible. Those who did not know how to classify a beneficiary were instructed to write the name in the appropriate space for 'other'. These beneficiaries were then manually assigned to the relevant categories during data cleaning.

The second question asked the corresponding authors to describe the nature of the research reported in the article. A drop-down list was provided, which included 13 descriptors. Eight of these were measures of the 'epistemological', 'intentional' and 'distance to application' criteria for basic research (Calvert 2004). The respondents were instructed to select all applicable descriptors, which also included instances of research aimed at application and broader utility (e.g. research that solves technical or applied problems, or research that contributes to economic growth, job creation and innovation).

Of the 6624 emails distributed, 6261 were successfully delivered and 2116 useable questionnaires were received. This represented a survey response of 34 per cent.

The analyses were performed using Microsoft Access and SPSS.

\section{RESULTS}

\section{Beneficiaries of university research}

Table 1 shows the 22 beneficiary categories, together with the responses of the 1956 corresponding authors who completed the question about the beneficiaries of the research in their article. Almost three quarters (73\%) of the respondents indicated the beneficiaries as their 
own university (i.e. their university at the time of conducting the research). The respondents' own university also ranked first in all broad fields, with figures ranging between 69 per cent

Table 1: Perceptions of the corresponding authors of the beneficiaries of their research

\begin{tabular}{|c|c|c|c|c|c|}
\hline \multirow[b]{2}{*}{ Beneficiaries: One or more individuals from ... } & \multirow[b]{2}{*}{$\begin{array}{l}\text { All } \\
\text { articles } \\
(1956)\end{array}$} & \multicolumn{4}{|c|}{ Broad scientific fields } \\
\hline & & $\begin{array}{l}\text { Agric. } \\
\text { Sc. } \\
\text { (186) }\end{array}$ & $\begin{array}{l}\text { Health } \\
\text { Sc. } \\
(408)\end{array}$ & $\begin{array}{l}\text { Nat. \& } \\
\text { Eng. } \\
\text { Sc. } \\
\text { (847) }\end{array}$ & $\begin{array}{l}\text { Soc. } \\
\text { Sc. \& } \\
\text { Hum. } \\
\text { (686) }\end{array}$ \\
\hline Own university & $73 \%$ & $69 \%$ & $75 \%$ & $74 \%$ & $72 \%$ \\
\hline \multicolumn{6}{|l|}{ Public sector in South Africa or in any other country } \\
\hline Other public universities/institutions of higher learning & $52 \%$ & $46 \%$ & $51 \%$ & $50 \%$ & $57 \%$ \\
\hline Ministries/departments/divisions in national/provincial government & $31 \%$ & $34 \%$ & $38 \%$ & $27 \%$ & $32 \%$ \\
\hline $\begin{array}{l}\text { Research organisations and research performing science councils } \\
\text { that report to government }\end{array}$ & $33 \%$ & $37 \%$ & $29 \%$ & $41 \%$ & $24 \%$ \\
\hline State-owned companies and parastatals & $9 \%$ & $13 \%$ & $7 \%$ & $11 \%$ & $6 \%$ \\
\hline Local government/municipalities & $15 \%$ & $16 \%$ & $15 \%$ & $15 \%$ & $14 \%$ \\
\hline National funding agencies or national funds & $13 \%$ & $16 \%$ & $10 \%$ & $18 \%$ & $8 \%$ \\
\hline $\begin{array}{l}\text { Public organisations that belong to government (e.g. courts, public } \\
\text { schools, state hospitals/clinics, public museums, public libraries) }\end{array}$ & $17 \%$ & $11 \%$ & $30 \%$ & $9 \%$ & $19 \%$ \\
\hline $\begin{array}{l}\text { Government-based development aid agencies (DFID/UKAID, IDRC, } \\
\text { NORAD, SIDA, USAID, etc.) }\end{array}$ & $8 \%$ & $8 \%$ & $10 \%$ & $5 \%$ & $9 \%$ \\
\hline $\begin{array}{l}\text { Inter-governmental organisations and their agencies (e.g. African } \\
\text { Union, European Union, African Development Bank, International } \\
\text { Energy Corporation, United Nations and its specialised agencies like } \\
\text { IMF, WHO, UNESCO, World Bank, etc.) }\end{array}$ & $9 \%$ & $7 \%$ & $12 \%$ & $7 \%$ & $11 \%$ \\
\hline \multicolumn{6}{|l|}{ Business/industry/private sector in South Africa or in any other country } \\
\hline Micro, small and medium businesses & $12 \%$ & $27 \%$ & $6 \%$ & $13 \%$ & $9 \%$ \\
\hline Large firms/companies, including multinationals & $15 \%$ & $26 \%$ & $9 \%$ & $19 \%$ & $11 \%$ \\
\hline Private research organisations & $11 \%$ & $20 \%$ & $6 \%$ & $12 \%$ & $10 \%$ \\
\hline $\begin{array}{l}\text { Private schools/colleges/learning institutions/higher education } \\
\text { institutions }\end{array}$ & $7 \%$ & $3 \%$ & $5 \%$ & $5 \%$ & $13 \%$ \\
\hline Private hospitals/clinics & $7 \%$ & $2 \%$ & $21 \%$ & $4 \%$ & $4 \%$ \\
\hline $\begin{array}{l}\text { Industry in the broad sense (wildlife industry, tourism industry, } \\
\text { chemical industry, etc.) }\end{array}$ & $14 \%$ & $32 \%$ & $7 \%$ & $18 \%$ & $9 \%$ \\
\hline \multicolumn{6}{|c|}{ Civil society/communities of interest/general public in South Africa or in any other country } \\
\hline $\begin{array}{l}\text { Charities and private foundations/trusts (Ford Foundation, Gates } \\
\text { Foundation, Kellogg Foundation, Mellon Foundation, Rockefeller } \\
\text { Foundation, Wellcome Trust, etc.) }\end{array}$ & $7 \%$ & $4 \%$ & $10 \%$ & $3 \%$ & $10 \%$ \\
\hline $\begin{array}{l}\text { Non-governmental organisations (NGOs), non-profit organisations } \\
\text { (NPOs), think-tanks, voluntary organisations and action groups }\end{array}$ & $16 \%$ & $13 \%$ & $18 \%$ & $10 \%$ & $24 \%$ \\
\hline Religious organisations/denominations and places of worship & $5 \%$ & $1 \%$ & $3 \%$ & $1 \%$ & $12 \%$ \\
\hline $\begin{array}{l}\text { Associations, societies and networks of individuals and } \\
\text { organisations }\end{array}$ & $14 \%$ & $15 \%$ & $15 \%$ & $8 \%$ & $21 \%$ \\
\hline $\begin{array}{l}\text { Specific professions/interest groups (e.g. engineers, demographers, } \\
\text { doctors, teachers, farmers, musicians, artists, hunters, sports } \\
\text { people, collectors) }\end{array}$ & $24 \%$ & $25 \%$ & $30 \%$ & $17 \%$ & $27 \%$ \\
\hline The general public & $20 \%$ & $12 \%$ & $25 \%$ & $14 \%$ & $27 \%$ \\
\hline
\end{tabular}

Notes: Beneficiaries are defined as those with a direct interest in the outcome of the research and those directly affected by the results of the research. The four broad fields were constructed from the subject categories of the WoS journals, according to the field classification framework by Boshoff (2010). These broad fields are not mutually exclusive as the WoS assigns journals to multiple subject categories.

(for agricultural sciences) and 75 per cent (for health sciences). The focus on one's own university as primary beneficiary, and other universities (52\%) and government-based research organisations (33\%) as secondary beneficiaries, implies that university research - or at least 
published university research seen from the perspective of the corresponding authors of articles in the WoS - is still largely produced for the research and academic community.

That being said, Table 1 also shows evidence of university research with perceived beneficiaries outside the research and academic community, although to a markedly lesser degree. Such beneficiaries tend to be government departments and ministries (31\%), specific interest groups such as doctors, teachers and farmers (24\%) and the general public (20\%). The general public is perceived as a beneficiary mainly by respondents in the health sciences (25\%) and the social sciences and humanities (27\%). Specific professions and interest groups, or communities of practice/interest, are also more frequently mentioned in the health sciences (30\%), followed by the social sciences and humanities (27\%). Of all four broad fields, the agricultural sciences have the largest shares of beneficiaries in the business sector: industry in the broad sense (32\%), micro, small and medium businesses (27\%) and large firms (26\%).

Since any respondent in Table 1 could have selected more than one beneficiary, the responses were not mutually exclusive. A cluster analysis was performed to identify mutually exclusive groups of corresponding authors that displayed a similar set of responses about their research beneficiaries. The objective was to segment the 1956 respondents into a manageable number of clusters that demonstrate maximum homogeneity within clusters and maximum heterogeneity between clusters. A hierarchical clustering method (Ward's method, using the squared Euclidean distance as dissimilarity measure) was performed to determine the appropriate number of clusters, followed by a non-hierarchical clustering method (K-means) to form the clusters (Hair, Anderson, Tatham and Black 1998). The outcome of these procedures was the allocation of each corresponding author to one of 11 mutually exclusive clusters with a new variable indicating cluster membership.

Table 2 reflects each of the 11 clusters in terms of the 22 variables that comprised the input for the cluster analysis. It gives the number of cases in each cluster (e.g. 248 respondents in cluster 1 and 162 in cluster 2) as well as the percentage of respondents in a cluster who regarded a given entity as a beneficiary. For instance, of the 248 respondents in cluster 1, all of them (100\%) stated that their own university was perceived as a beneficiary in their research. Similarly, of the 120 respondents in cluster 9, 89 per cent reported ministries and national government divisions as research beneficiaries, 73 per cent reported NGOs, NPOs and voluntary groups, and 60 per cent, local governments and municipalities. The dark-shaded cells in Table 2 highlight the beneficiaries that were mentioned by 80-100 per cent of corresponding authors, and the light-shaded cells are those mentioned by 60-79 per cent. These two sets of cells informed the assignment of labels to describe the nature of the clusters appropriately. The respective labels were: 
- $\quad$ Cluster 1 ('Own university'): All respondents in this cluster specified their own university, or any individual associated with that university, as the main beneficiary of their research. Beneficiaries other than the own university were rarely mentioned.

- $\quad$ Cluster 2 ('National funding agency and own university'): All respondents in this cluster indicated that their work had direct value for a national funding agency or that the agency had a direct interest in the outcome of their study. Moreover, 95 per cent of these respondents also specified their own university as a beneficiary in addition to the national funding agency. Hence, the cluster represents publicly funded research at universities, for instance, university research that is funded by the South African National Research Foundation (NRF).

- $\quad$ Cluster 3 ('Public universities'): All respondents in cluster 3 viewed a public university as the primary beneficiary of their research, which includes their own university in 90 per cent of the cases. Beneficiaries outside the public university sector were rarely mentioned.

- Cluster 4 ('Public research organisations'): All respondents in cluster 4 considered government-based research organisations (e.g. the South African research-performing science councils) to be their main beneficiary. Since large proportions of respondents also specified their own (80\%) or another public university (61\%) as either interested in or affected by the outcome of the research, the audience of this cluster is best described as 'public research organisations'.

- $\quad$ Cluster 5 ('Government and public universities'): Government departments and divisions were perceived as research beneficiaries by all respondents (100\%) in this cluster. Also included as beneficiaries were the respondents' own universities (91\%) and, to a lesser degree, other public universities (69\%).

- Cluster 6 ('Public universities and communities of interest/practice'): The majority of respondents in this cluster regarded a specific interest group (e.g. farmers, nurses or teachers) as the primary beneficiary of their research (83\%). This was in addition to a public university that was either the respondent's own university (94\%) or another university (81\%). Specific interest groups are often organised within networks and associations and contribute towards the betterment of society through their respective activities. It therefore came as no surprise that relatively large percentages of respondents in this cluster also included associations, societies and networks (79\%) and the general public (70\%) as beneficiaries.

- Cluster 7 ('All sectors of society'): This cluster was the most representative as the respondents indicated the presence of multiple beneficiaries from all sectors of society. 
These included the public university sector (own and other public universities, $90 \%$ and 88\% respectively), the government sector (e.g. government-based research organisations, 92\%; and government departments/ministries, 83\%), the private sector (e.g. private research organisations, 94\%; and large firms, 83\%), communities of interest/practice (e.g. specific interest groups, 83\%; and societies/associations, 73\%) and the general public (65\%).

- $\quad$ Cluster 8 ('Public research organisations and civil society'): Research institutions in the public sector, which included own and other universities (94\% and 92\%) and governmentbased research organisations (85\%), were the main beneficiaries in this cluster. This was in addition to a host of public organisations that either represent the interests of civil society (government departments/ministries, 91\%; and NGOs, NPOs, think-tanks, voluntary organisations and action groups, 71\%) or serve to support civil society (e.g. foreign government-based development aid agencies, 70\%; and inter-governmental organisations and their agencies, 71\%).

- Cluster 9 ('Government and civil society'): All levels of government are included as beneficiaries in this cluster (national/provincial government, 89\%; and local government/municipalities, 60\%), together with representatives from civil society (i.e. NGOs, NPOs, think-tanks, voluntary organisations and action groups, 73\%).

- $\quad$ Cluster 10 ('Large firms'): Altogether 99 per cent of respondents in this cluster identified large firms, including multinationals, as the beneficiaries of their research. Trailing behind in the second place (52\%), were micro, small and medium enterprises, which confirmed that this cluster was essentially a business cluster.

- $\quad$ Cluster 11 ('Diverse beneficiaries but excluding public research organisations'): There were three defining features of this cluster. Firstly, the respondents' own universities did not feature as beneficiaries (0\%). Secondly, other public universities and governmentbased research organisations were equally absent - only 2 per cent and 4 per cent of respondents selected these two categories. Thirdly, no single beneficiary was predominant as none was selected by more than 40 per cent of respondents.

Figure 1 gives the percentage distribution of the 11 clusters. Three have an almost exclusive focus on the research and academic community (cluster 3-19\%; cluster 1-13\%; cluster 4-10\%), with a combined share of 42 per cent. Moreover, only 3 per cent of corresponding authors reported that their beneficiaries were from multiple sectors, which included the university and government and private sectors (cluster 7). 
Table 2: Cluster variate profile for the 11-cluster solution

\begin{tabular}{|c|c|c|c|c|c|c|c|c|c|c|c|c|}
\hline \multirow{2}{*}{\multicolumn{2}{|c|}{ Beneficiaries: One or more individuals from ... }} & \multicolumn{11}{|c|}{ Clusters } \\
\hline & & $\begin{array}{l}\text { C1 } \\
(248)\end{array}$ & $\begin{array}{l}\text { C2 } \\
(162)\end{array}$ & $\begin{array}{l}\text { C3 } \\
(365)\end{array}$ & $\begin{array}{l}\text { C4 } \\
(200)\end{array}$ & $\begin{array}{l}\text { C5 } \\
(200)\end{array}$ & $\begin{array}{l}\text { C6 } \\
(135)\end{array}$ & $\begin{array}{l}\text { C7 } \\
(52)\end{array}$ & $\begin{array}{l}\text { C8 } \\
(98)\end{array}$ & $\begin{array}{l}\text { C9 } \\
(120)\end{array}$ & $\begin{array}{l}\text { C10 } \\
(157)\end{array}$ & $\begin{array}{l}\text { C11 } \\
(219)\end{array}$ \\
\hline \multicolumn{2}{|c|}{ Own university } & $100 \%$ & $95 \%$ & $90 \%$ & $80 \%$ & $91 \%$ & $94 \%$ & $90 \%$ & $94 \%$ & $19 \%$ & $43 \%$ & $0 \%$ \\
\hline \multirow{21}{*}{ 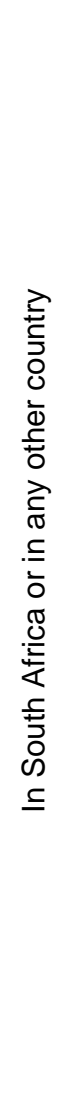 } & Other public universities/institutions of higher learning & $0 \%$ & $59 \%$ & $100 \%$ & $61 \%$ & $69 \%$ & $81 \%$ & $88 \%$ & $92 \%$ & $8 \%$ & $23 \%$ & $2 \%$ \\
\hline & Ministries/departments/divisions in national/provincial government & $0 \%$ & $31 \%$ & $0 \%$ & $0 \%$ & $100 \%$ & $30 \%$ & $83 \%$ & $91 \%$ & $89 \%$ & $15 \%$ & $21 \%$ \\
\hline & $\begin{array}{l}\text { Research organisations and research-performing science councils that report to } \\
\text { government }\end{array}$ & $0 \%$ & $49 \%$ & $0 \%$ & $100 \%$ & $43 \%$ & $36 \%$ & $92 \%$ & $85 \%$ & $39 \%$ & $23 \%$ & $4 \%$ \\
\hline & State-owned companies and parastatals & $3 \%$ & $9 \%$ & $2 \%$ & $6 \%$ & $12 \%$ & $1 \%$ & $65 \%$ & $29 \%$ & $12 \%$ & $15 \%$ & $5 \%$ \\
\hline & Local government/municipalities & $4 \%$ & $11 \%$ & $4 \%$ & $7 \%$ & $18 \%$ & $4 \%$ & $62 \%$ & $53 \%$ & $60 \%$ & $8 \%$ & $8 \%$ \\
\hline & National funding agencies or national funds & $0 \%$ & $100 \%$ & $0 \%$ & $0 \%$ & $0 \%$ & $10 \%$ & $56 \%$ & $30 \%$ & $12 \%$ & $2 \%$ & $3 \%$ \\
\hline & Public organisations that belong to government & $7 \%$ & $9 \%$ & $8 \%$ & $11 \%$ & $18 \%$ & $30 \%$ & $42 \%$ & $61 \%$ & $35 \%$ & $4 \%$ & $17 \%$ \\
\hline & Government-based development aid agencies & $0 \%$ & $1 \%$ & $1 \%$ & $4 \%$ & $2 \%$ & $1 \%$ & $42 \%$ & $70 \%$ & $24 \%$ & $1 \%$ & $5 \%$ \\
\hline & Inter-governmental organisations and their agencies & $2 \%$ & $5 \%$ & $1 \%$ & $6 \%$ & $7 \%$ & $5 \%$ & $58 \%$ & $71 \%$ & $21 \%$ & $3 \%$ & $4 \%$ \\
\hline & Micro, small and medium businesses & $7 \%$ & $7 \%$ & $4 \%$ & $4 \%$ & $3 \%$ & $4 \%$ & $75 \%$ & $10 \%$ & $15 \%$ & $52 \%$ & $7 \%$ \\
\hline & Large firms/companies, including multinationals & $0 \%$ & $15 \%$ & $5 \%$ & $5 \%$ & $8 \%$ & $4 \%$ & $83 \%$ & $12 \%$ & $10 \%$ & $99 \%$ & $1 \%$ \\
\hline & Private research organisations & $3 \%$ & $10 \%$ & $4 \%$ & $13 \%$ & $7 \%$ & $11 \%$ & $94 \%$ & $17 \%$ & $10 \%$ & $21 \%$ & $4 \%$ \\
\hline & Private schools/colleges/learning institutions/higher education institutions & $2 \%$ & $2 \%$ & $7 \%$ & $6 \%$ & $6 \%$ & $19 \%$ & $62 \%$ & $16 \%$ & $5 \%$ & $4 \%$ & $2 \%$ \\
\hline & Private hospitals/clinics & $1 \%$ & $3 \%$ & $5 \%$ & $4 \%$ & $6 \%$ & $10 \%$ & $37 \%$ & $18 \%$ & $7 \%$ & $4 \%$ & $8 \%$ \\
\hline & Industry in the broad sense & $11 \%$ & $14 \%$ & $4 \%$ & $12 \%$ & $10 \%$ & $12 \%$ & $83 \%$ & $13 \%$ & $15 \%$ & $27 \%$ & $17 \%$ \\
\hline & Charities and private foundations & $2 \%$ & $2 \%$ & $2 \%$ & $1 \%$ & $4 \%$ & $18 \%$ & $31 \%$ & $36 \%$ & $16 \%$ & $3 \%$ & $4 \%$ \\
\hline & NGOs, NPOs, think-tanks, voluntary organisations and action groups & $3 \%$ & $7 \%$ & $4 \%$ & $5 \%$ & $9 \%$ & $31 \%$ & $54 \%$ & $71 \%$ & $73 \%$ & $6 \%$ & $8 \%$ \\
\hline & Religious organisations/denominations and places of worship & $4 \%$ & $1 \%$ & $2 \%$ & $1 \%$ & $1 \%$ & $26 \%$ & $17 \%$ & $14 \%$ & $6 \%$ & $1 \%$ & $3 \%$ \\
\hline & Associations, societies and networks of individuals/organisations & $4 \%$ & $4 \%$ & $3 \%$ & $3 \%$ & $2 \%$ & 79 & 73 & $28 \%$ & $34 \%$ & $4 \%$ & $11 \%$ \\
\hline & Specific professions/interest groups & $11 \%$ & $10 \%$ & $10 \%$ & $7 \%$ & $14 \%$ & $83 \%$ & $83 \%$ & $58 \%$ & $27 \%$ & $8 \%$ & $37 \%$ \\
\hline & The general public & $10 \%$ & $7 \%$ & $5 \%$ & $7 \%$ & $9 \%$ & 70 & 65 & $34 \%$ & $51 \%$ & $15 \%$ & $26 \%$ \\
\hline
\end{tabular}






Figure 1: Distribution of the 11 clusters of beneficiaries of university research $(n=1956)$

\section{Nature of the university research}

The respondents were given a list of 13 descriptors and asked to select those that best described the research in their article (Table 3). Multiple selections were possible. Eight descriptors measured the 'epistemological' (five items), 'intentional' (two items) and 'distance from application' (one item) criteria for basic research. Four items were included as instances of research aimed at application and broader utility. These are presented in Table 3 under the label 'utility research'. Lastly, a single item was included that focussed on research for capacity building, i.e. whether supervision of postgraduate students formed part of the project.

Two of the measures appeared to be prominent indicators of basic research: (1) the reductionist nature of the generated knowledge, where the aim was to understand a phenomenon in terms of its basic entities, and (2) the intention of the researcher, specifically the intention to follow one's own curiosity. Percentages for both these measures were high across all scientific fields (40\% to 53\%). In the social sciences and humanities, a third criterion for basic research also dominated, namely the extent to which the research was driven by the theoretical dynamics of the field (47\%). However, Table 3 does not provide strong support for the claim that basic research either has no specific application in mind or is still far removed from application. Only small percentages of respondents (10\% and $9 \%)$ selected the latter two criteria, compared to significantly larger percentages of respondents who selected the other criteria for basic research. 
Table 3: Descriptors of the nature of the research by broad scientific field

\begin{tabular}{|c|c|c|c|c|c|}
\hline \multirow[b]{2}{*}{ Research descriptors } & \multirow[b]{2}{*}{$\begin{array}{l}\text { All } \\
\text { articles } \\
(2 \text { 107) }\end{array}$} & \multicolumn{4}{|c|}{ Broad scientific fields } \\
\hline & & $\begin{array}{l}\text { Agric. } \\
\text { Sc. } \\
\text { (202) }\end{array}$ & $\begin{array}{l}\text { Health } \\
\text { Sc. } \\
\text { (435) }\end{array}$ & $\begin{array}{l}\text { Nat. \& } \\
\text { Eng. } \\
\text { Sc. } \\
(927)\end{array}$ & $\begin{array}{l}\text { Soc. } \\
\text { Sc. \& } \\
\text { Hum. } \\
(733)\end{array}$ \\
\hline \multicolumn{6}{|l|}{ Basic research: 'Epistemological' criterion } \\
\hline $\begin{array}{l}\text { Research that contributes to the generalised } \\
\text { understanding of phenomena in terms of their most } \\
\text { basic entities }\end{array}$ & $46 \%$ & $53 \%$ & $43 \%$ & $51 \%$ & $41 \%$ \\
\hline Research that is unpredictable and novel & $37 \%$ & $35 \%$ & $38 \%$ & $42 \%$ & $33 \%$ \\
\hline $\begin{array}{l}\text { Research that is driven by the theoretical dynamics of } \\
\text { the field }\end{array}$ & $37 \%$ & $29 \%$ & $26 \%$ & $34 \%$ & $47 \%$ \\
\hline Research that solves theoretical problems & $23 \%$ & $16 \%$ & $12 \%$ & $26 \%$ & $28 \%$ \\
\hline $\begin{array}{l}\text { Research that applies to a wide range of instances and } \\
\text { phenomena }\end{array}$ & $20 \%$ & $16 \%$ & $17 \%$ & $20 \%$ & $24 \%$ \\
\hline \multicolumn{6}{|l|}{ Basic research: 'Intentional' criterion } \\
\hline Research that is curiosity-driven & $46 \%$ & $40 \%$ & $40 \%$ & $48 \%$ & $48 \%$ \\
\hline Research that has no specific application in mind & $10 \%$ & $8 \%$ & $3 \%$ & $12 \%$ & $11 \%$ \\
\hline \multicolumn{6}{|l|}{ Basic research: 'Distance from application' criterion } \\
\hline Research that is still far removed from application & $9 \%$ & $6 \%$ & $5 \%$ & $14 \%$ & $6 \%$ \\
\hline \multicolumn{6}{|l|}{ Utility research } \\
\hline Research that solves technical or applied problems & $32 \%$ & $46 \%$ & $29 \%$ & $45 \%$ & $16 \%$ \\
\hline Research that solves social or environmental problems & $30 \%$ & $33 \%$ & $26 \%$ & $29 \%$ & $33 \%$ \\
\hline $\begin{array}{l}\text { Research that addresses the specified grand challenges } \\
\text { of a country/region }\end{array}$ & $29 \%$ & $35 \%$ & $34 \%$ & $23 \%$ & $30 \%$ \\
\hline $\begin{array}{l}\text { Research that contributes to economic growth, job } \\
\text { creation and innovation }\end{array}$ & $13 \%$ & $23 \%$ & $7 \%$ & $16 \%$ & $12 \%$ \\
\hline \multicolumn{6}{|l|}{ Research for capacity building } \\
\hline $\begin{array}{l}\text { Research that involves supervision of one or more } \\
\text { postgraduate students for degree purposes }\end{array}$ & $40 \%$ & $55 \%$ & $41 \%$ & $52 \%$ & $22 \%$ \\
\hline
\end{tabular}

As far as utility research is concerned, the solving of technical or applied problems was highest among respondents in the agricultural sciences (46\%) and the natural and engineering sciences (45\%). Research for capacity building was high across all fields (40-55\%), with the exception of the social sciences and humanities (22\%). This means that, compared to the other fields, published research in the social sciences and humanities - and specifically published research in the mainly international social sciences literature that lists a South African-based corresponding author - is less likely to involve the supervision of postgraduate students.

The twelve items for basic and utility research were used to create a composite measure of research type that comprised three categories. The first category, 'basic research only', included corresponding authors who selected at least one of the eight criteria for basic research but none of the four criteria for utility research. The 'utility research only' category comprised corresponding authors who selected one or more of the criteria for utility research but none of the criteria for basic research. Corresponding authors were classified in the 'both basic and utility research' category if they selected at least one criterion for basic research and at least 
one criterion for utility research. Figure 2 shows the breakdown of articles in terms of this threecategory measure of research type.

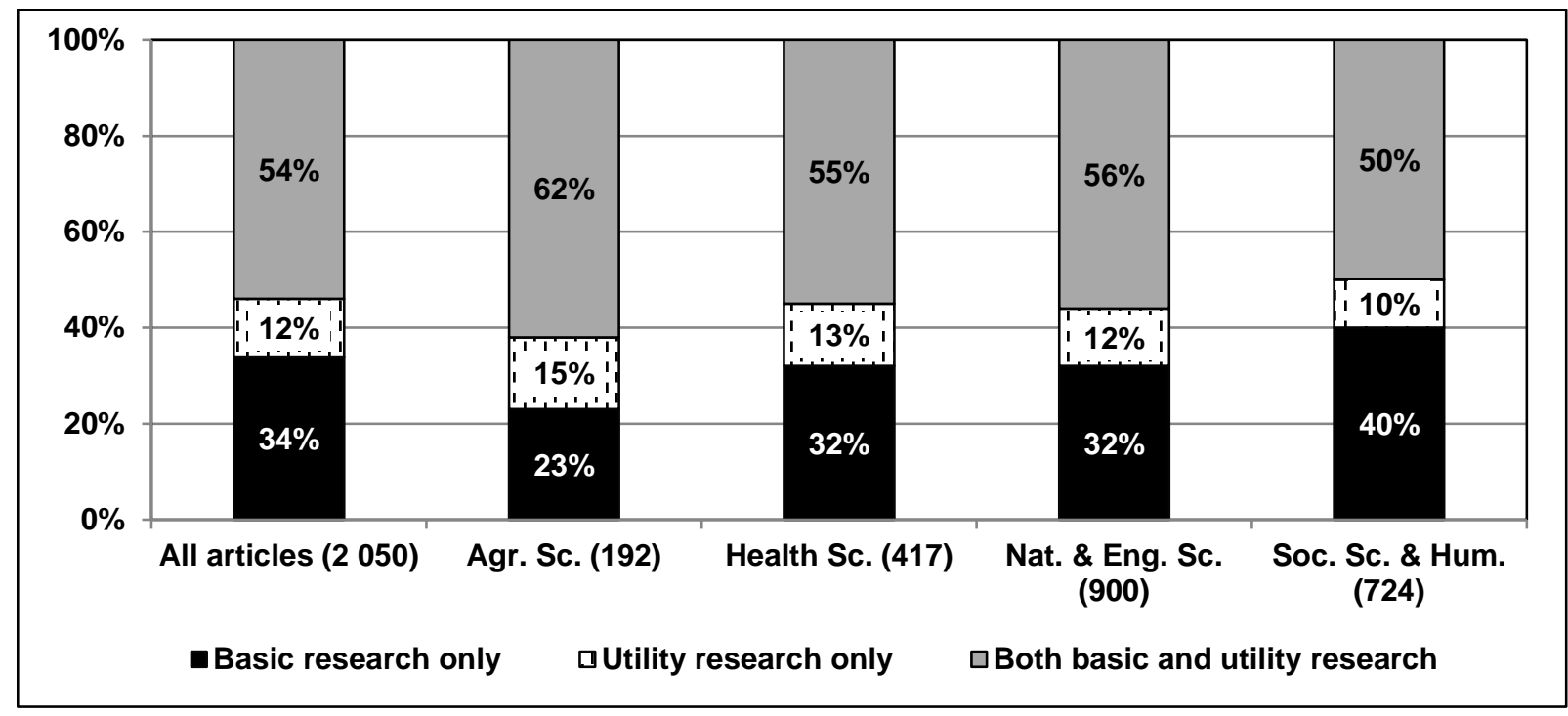

Notes: The article totals are less than those in Table 3. Fifty-seven respondents are excluded here as they described their research solely as postgraduate supervision and did not select any of the other descriptors corresponding to basic or utility research. See Figure 1 for the cluster labels.

Figure 2: Breakdown of research in terms of basic and utility research by broad scientific field

Significantly more articles were classifiable as 'basic research only’ than 'utility research only' (34\% versus 12\%). This was also true for the broad fields. Between 50 per cent (social sciences and humanities) and 62 per cent (agricultural sciences) of corresponding authors described their research in terms of basic research criteria only. Considerations of utility, on the other hand, rarely seemed to occur in the absence of the criteria for basic research. Overall, 88 per cent of the 2050 articles in Figure 2 involved some element of basic research, either with or without considerations of utility also being present.

\section{Research beneficiary clusters and the nature of university research}

Table 4 presents the relationship between the eight descriptors of basic research and the 11 beneficiary categories, by providing the distribution of beneficiaries per descriptor of basic research. The key observation is that, compared to the overall cluster distribution, research with no specific application in mind seems to be mainly concentrated in cluster 3 (public universities as primary beneficiary, 28\%) and cluster 1 (own university as primary beneficiary, 20\%). Moreover, respectively 33 per cent and 59 per cent of 'pure basic research’ and ‘oriented basic research' projects were located in clusters that included a broader range of beneficiaries in addition to the public research and academic communities (the percentages were derived from the sum of figures for clusters 5 to 11). 
Table 4: Breakdown of descriptors of basic research in terms of 11 clusters

\begin{tabular}{|c|c|c|c|c|c|c|c|c|c|c|c|c|}
\hline \multirow{2}{*}{ Descriptors of basic research } & \multicolumn{11}{|c|}{ Clusters } & \multirow{2}{*}{ All } \\
\hline & C1 & C2 & C3 & C4 & C5 & C6 & C7 & C8 & C9 & C10 & C11 & \\
\hline \multicolumn{13}{|c|}{ Basic research: 'Epistemological' criterion } \\
\hline $\begin{array}{l}\text { Research that contributes to } \\
\text { the generalised understanding } \\
\text { of phenomena in terms of their } \\
\text { most basic entities }\end{array}$ & $12 \%$ & $10 \%$ & $19 \%$ & $11 \%$ & $10 \%$ & $7 \%$ & $3 \%$ & $5 \%$ & $5 \%$ & $8 \%$ & $10 \%$ & $\begin{array}{l}100 \% \\
(1046)\end{array}$ \\
\hline $\begin{array}{l}\text { Research that is unpredictable } \\
\text { and novel }\end{array}$ & $13 \%$ & $11 \%$ & $19 \%$ & $13 \%$ & $9 \%$ & $6 \%$ & $3 \%$ & $5 \%$ & $6 \%$ & $7 \%$ & $9 \%$ & $\begin{array}{l}100 \% \\
(731)\end{array}$ \\
\hline $\begin{array}{l}\text { Research that is driven by the } \\
\text { theoretical dynamics of the } \\
\text { field }\end{array}$ & $12 \%$ & $9 \%$ & $21 \%$ & $10 \%$ & $9 \%$ & $9 \%$ & $3 \%$ & $5 \%$ & $6 \%$ & $6 \%$ & $10 \%$ & $\begin{array}{l}100 \% \\
(714)\end{array}$ \\
\hline $\begin{array}{l}\text { Research that solves } \\
\text { theoretical problems }\end{array}$ & $12 \%$ & $11 \%$ & $22 \%$ & $11 \%$ & $7 \%$ & $9 \%$ & $3 \%$ & $6 \%$ & $4 \%$ & $6 \%$ & $8 \%$ & $\begin{array}{l}100 \% \\
(450)\end{array}$ \\
\hline $\begin{array}{l}\text { Research that applies to a } \\
\text { wide range of instances and } \\
\text { phenomena }\end{array}$ & $10 \%$ & $10 \%$ & $13 \%$ & $11 \%$ & $10 \%$ & $10 \%$ & $6 \%$ & $8 \%$ & $7 \%$ & $5 \%$ & $10 \%$ & $\begin{array}{l}100 \% \\
(388)\end{array}$ \\
\hline \multicolumn{13}{|l|}{ Basic research: 'Intentional' criterion } \\
\hline $\begin{array}{l}\text { Research that is curiosity- } \\
\text { driven }\end{array}$ & $14 \%$ & $9 \%$ & $19 \%$ & $12 \%$ & $10 \%$ & $8 \%$ & $2 \%$ & $4 \%$ & $6 \%$ & $6 \%$ & $10 \%$ & $\begin{array}{l}100 \% \\
(898)\end{array}$ \\
\hline $\begin{array}{l}\text { Research that has no specific } \\
\text { application in mind }\end{array}$ & $20 \%$ & $11 \%$ & $28 \%$ & $14 \%$ & $1 \%$ & $6 \%$ & $2 \%$ & $2 \%$ & $3 \%$ & $2 \%$ & $12 \%$ & $\begin{array}{l}100 \% \\
(188)\end{array}$ \\
\hline \multicolumn{13}{|c|}{ Basic research: 'Distance from application' criterion } \\
\hline $\begin{array}{l}\text { Research that is still far } \\
\text { removed from application }\end{array}$ & $14 \%$ & $14 \%$ & $25 \%$ & $17 \%$ & $4 \%$ & $5 \%$ & $2 \%$ & $1 \%$ & $3 \%$ & $6 \%$ & $10 \%$ & $\begin{array}{l}100 \% \\
(162)\end{array}$ \\
\hline $\begin{array}{l}\text { Pure basic research (basic } \\
\text { research only) }\end{array}$ & $16 \%$ & $8 \%$ & $32 \%$ & $12 \%$ & $6 \%$ & $8 \%$ & $<1 \%$ & $1 \%$ & $3 \%$ & $4 \%$ & $11 \%$ & $\begin{array}{l}100 \% \\
(618)\end{array}$ \\
\hline $\begin{array}{l}\text { Oriented basic research (both } \\
\text { basic and utility research) }\end{array}$ & $10 \%$ & $9 \%$ & $13 \%$ & $10 \%$ & $12 \%$ & $7 \%$ & $4 \%$ & $7 \%$ & $8 \%$ & $10 \%$ & $11 \%$ & $\begin{array}{l}100 \% \\
(1049)\end{array}$ \\
\hline Overall cluster distribution & $13 \%$ & $8 \%$ & $19 \%$ & $10 \%$ & $10 \%$ & $7 \%$ & $3 \%$ & $5 \%$ & $6 \%$ & $8 \%$ & $11 \%$ & $\begin{array}{l}100 \% \\
(1947)\end{array}$ \\
\hline
\end{tabular}

Notes: Percentages do not add to 100 per cent in every row because of rounding. See Figure 1 for the cluster labels.

\section{DISCUSSION}

As a first contribution, the current study suggests an answer as to whether South African university research projects have beneficiaries other than the academic and research community. The answer, though, is not a straightforward 'yes' or 'no'. On the one hand, the study provided evidence of university research in South Africa that is very 'inward-looking' in terms of those directly affected by the research or those with a direct interest in the research outcome. As reported, 73 per cent of the corresponding authors considered their beneficiaries to be one or more individuals from their own university. On the other hand, if the overlap of the different categories of beneficiaries in a single project is controlled for - as was done through the creation of mutually exclusive clusters of beneficiaries - then only 13 per cent of projects (cluster 1) were solely focussed on researchers' own universities as research beneficiary. The figure again rises to 42 per cent if a beneficiary is taken to mean any public university or any public research organisation (clusters 1, 3 and 4). At the same time, the study provided evidence of a critically low percentage of projects (3\%) that had multiple beneficiaries representing all sectors of society (academia/research, government, industry and civil society). 
A second contribution of the study is the insight it provides into basic research, specifically the measuring challenge of accurately capturing instances of basic research. The same group of respondents, reporting on the same set of projects, produced two significantly different percentages for two commonly accepted descriptors of basic research - research that is curiosity-driven (46\%) and research that is far removed from application (9\%). This study thus also exposed the risk of overlooking some instances of basic research if the latter is solely defined as the 'inverse' of application, i.e. as research that lacks application or research that is still far from application. In cluster 5, for instance, where the beneficiaries are government entities and public universities, these two descriptors of basic research characterised respectively 1 per cent and 3 per cent of projects. However, when considering additional criteria for basic research, 19 per cent and 65 per cent of projects in the same cluster can be classified as 'pure basic research’ and ‘oriented basic research’ respectively. Thus, there is much truth in the comment by Salter and Martin $(2001,510)$ that 'research can have different objectives depending on the perspective of the observer' and, to which one may add in the case of basic research, the particular descriptor used.

The current study also revealed that basic research projects do have beneficiaries other than the scientific community, who either have a direct interest in the research outcome or who are directly affected by the research results. These beneficiaries ranged from the specific (e.g. a government department or business) to the more diffuse (the general public). Not all of these beneficiaries, though, could be explained by the co-existence of basic and applied research activities in the same projects, given that 33 per cent of the 'pure basic research' projects also included 'broader' beneficiaries. It thus seems plausible that researchers who undertake basic research activities can also reflect on the non-academic contribution of their research. Researchers in the biomedical sciences at Harvard University, for instance, did exactly that, which led the authors of that study to conclude that the most important goal of biomedical basic research is 'producing health benefits to society and that both use-oriented and non-use-oriented research can make such impact' (Boggio et al. 2016, 171).

It could be asked what the implications of the current study's findings are for higher education in South Africa. The findings suggest that basic research and a traditional academic orientation are largely still a preoccupation of South African universities. This coincides with a growing body of similar findings for international universities (e.g. Bentley et al. 2015; Ylijoki, Lyytinen and Marttila 2011), which all seem to argue against a central proposition in the Mode 2 discourse of knowledge production, namely that research which is variously described as 'pure', ‘blue-skies', fundamental, or disinterested, is now a minority preoccupation 
- even in universities' (Nowotny, Scott and Gibbons 2003, 184). In fact, 88 per cent of all projects in the current study involved some aspect of basic research, of which 54 per cent incorporated utility research. In South Africa, as elsewhere in the world, 'basic research retains a core position within the research mind sets of most academics' (Bentley et al. 2015, 705). The co-occurrence of basic and utility research emerged as a common feature of knowledge production at South African universities, irrespective of university type (see last column in Table 5). In terms of strategies of funding support for university research, then, it is not necessarily a case of deciding between research for the sake of knowledge discovery and research that includes considerations of use. It is rather a case of finding middle ground given that basic and utility research can comfortably co-exist.

Table 5: Breakdown of research in terms of basic and utility research by type of South African university

\begin{tabular}{|l|l|l|l|}
\hline Type of university & $\begin{array}{l}\text { Basic research } \\
\text { only }\end{array}$ & $\begin{array}{l}\text { Utility research } \\
\text { only }\end{array}$ & $\begin{array}{l}\text { Both basic and } \\
\text { utility research }\end{array}$ \\
\hline Traditional universities $(\mathrm{N}=1738)$ & $34 \%$ & $12 \%$ & $54 \%$ \\
\hline Comprehensive universities $(\mathrm{N}=226)$ & $37 \%$ & $11 \%$ & $52 \%$ \\
\hline Universities of technology $(\mathrm{N}=86)$ & $15 \%$ & $26 \%$ & $59 \%$ \\
\hline
\end{tabular}

The patterns of association between the research types and clusters of research beneficiaries in the current study further suggest that new conceptualisations of research in higher education need to be explored. Such conceptualisations should not only consider aspects of knowledge production but also the role played by research beneficiaries and other categories of research stakeholders in the research process. A promising development is the multi-dimensional typology of research by McNie, Parris and Sarewitz (2016). Research is seen as comprising three general activities, namely knowledge production, learning and engagement, and organisational and institutional processes. Each of these involves numerous attributes to capture 'the complexity and diversity of the contexts for conducting and using research’ (McNie, Parris and Sarewitz 2016, 884).

Finally, as is the case with any research, the current study also had limitations. For instance, it could be argued that the two multiple-response questions did not collect factual information about research and its beneficiaries but rather the opinions of researchers as to the nature and beneficiaries of their research. This would make it impossible to determine whether some respondents merely found it important to state that beneficiaries were involved. Still, the responses revealed an underlying logic and consistency that conformed to general expectations, such as that research with no specific application in mind would predominantly be concentrated in clusters with public universities as primary beneficiaries. It also needs to be emphasised that the current study excluded all South African articles in the WoS where the corresponding author 
had a non-South African address as well as all South African articles published in journals that are not indexed by the WoS. According to data not available in the public domain (from the Centre for Research on Evaluation, Science and Technology [CREST] at Stellenbosch University), only 61 of South Africa's 318 peer-reviewed journals are currently indexed by the WoS. This means that the current study in no way considered the full spectrum of published research.

\section{REFERENCES}

Alves, H., E. M. Mainardes and M. Raposo. 2010. A relationship approach to higher education institution stakeholder management. Tertiary Education and Management 16(3): 159-181.

Bentley, P. J., M. Gulbrandsen and S. Kyvik. 2015. The relationship between basic and applied research in universities. Higher Education 70: 689-709.

Boggio, A., A. Ballabeni and D. Hemenway. 2016. Basic research and knowledge production modes: A view from the Harvard Medical School. Science, Technology \& Human Values 41(2): 163-193.

Boshoff, N. 2010. South-South research collaboration of countries in the Southern African Development Community (SADC). Scientometrics 84(2): 481-503.

Calvert, J. 2004. The idea of 'basic research' in language and practice. Minerva 42: 251-268.

Freeman, R. E. 1984. The politics of stakeholder theory: Some future directions. Business Ethics Quarterly 4(4): 409-422.

Hair, J. F. Jnr., R. E. Anderson, R. L. Tatham and W. C. Black. 1998. Multivariate data analysis. 5th Edition. Upper Saddle River, NJ: Prentice Hall.

Hessels, L. K. and H. van Lente. 2008. Re-thinking new knowledge production: A literature review and a research agenda. Research Policy 37: 740-760.

McNie, E. C., A. Parris and D. Sarewitz. 2016. Improving the public value of science: A typology to inform discussion, design and implementation of research. Research Policy 45: 994-895.

Milligan, J., J. Hills, T. Smith and M. le Tissier. 2004. A typology of coastal researchers' modes of interactions with stakeholders. Journal of Science Communication 3(3): 1-11.

Mouton, J. 2001. Between adversaries and allies: The call for strategic science in post-apartheid South Africa. Society in Transition 32: 155-172.

Nowotny, H., P. Scott and M. Gibbons. 2003. Introduction: 'Mode 2' revisited: The new production of knowledge. Minerva 41(3): 179-194.

OECD see Organisation for Economic Co-operation and Development

Organisation for Economic Co-operation and Development. 2002. Frascati manual. Proposed standard practice for surveys on research and experimental development. Paris: OECD.

Salter, A. J. and B. R. Martin. 2001. The economic benefits of publicly funded basic research: A critical review. Research Policy 30: 509-532.

Stokes, D. E. 1997. Pasteur's quadrant: Basic science and technological innovation. Washington, DC: Brookings Institution Press.

Ylijoki, O.-H., A. Lyytinen and L. Marttila. 2011. Different research markets: A disciplinary perspective. Higher Education 62: 721-740. 